\title{
Avian Paramyxoviruses. Detection by Transmission Electron Microscopy Techniques
}

\author{
Paramixovirus Aviario. Detección por Técnicas de Microscopía Electrónica de Transmisión \\ "Catroxo, M. H. B.; "Martins, A. M. C. P. F.; "* Petrella, S.; ${ }^{* * *}$ Milanelo, L.; "Aschar, M.; "Souza, F.; "Nastari, B.D.B.; "Souza, R.B.
}

CATrOXO, M.H.B.; MARTINS, A.M.C.P.F.; PETRELLA, S.; MILANELO, L.; ASCHAR, M.; SOUZA, F.; NASTARI, B.D.B.; SOUZA, R.B. Avian paramyxoviruses. Detection by transmission electron microscopy techniques. Int. J. Morphol., 30(2):723-730, 2012.

SUMMARY: Diseases caused by avian paramyxovirus (APMV) occur in commercial, captive and wild birds worldwide, demonstrating the significant economic and ecological importance of these agents. Paramyxoviruses belong to the Paramyxoviridae family, Paramyxovirinae subfamily and Avulavirus genus. During the period 2000 to 2011, stool and small intestine samples of 1647 birds species were sent to the Laboratory of Electron Microscopy, Biological Institute of São Paulo, Brazil, for diagnosis of viral agents. The samples were processed by negative staining (rapid preparation) and resin embedding techniques. Under the transmission electron microscope by negative staining technique, in 294 (17.8\%) samples of 1647 were visualized paramyxovirus particles pleomorphic, roughly spherical or filamentous, measuring 100 to $500 \mathrm{~nm}$ of diameter containing an envelope covered with spikes and characteristic helical herring-bone-like nucleocapsid measuring 15 to $20 \mathrm{~nm}$ in diameter. Ultrathin sections of the small intestine fragments revealed the presence of amorphous granular intracytoplasmic inclusions surrounded by membrane and containing viral nucleocapsid measuring 10-14 nm in diameter. Immature particles budding from cell membranes, pleomorphic, spherical and tubular particles containing viral nucleocapsid strands, and the complete particles measured up to $170 \mathrm{~nm}$ in diameter were seen in the cytoplasm. Intranuclear inclusions containing viral nucleocapsid were also visualized. Nuclei showed a marginalized chromatin.

KEYWORDS: Paramyxoviruses, Avian, Transmission Electron Microscopy.

\section{INTRODUCTION}

The worldwide occurrence of diseases caused by avian paramyxoviruses (APMV) in commercial, captive and wild birds, demonstrates significant economic and ecological importance of these agents (Kaleta \& Broden, 1994).

Avian paramyxoviruses belong to the Paramyxoviridae family, Paramyxovirinae subfamily and Avulovirus genus (ICTV, 2011).

They are pleomorphic, usually elongated or filamentous, measuring $100-300 \mathrm{~nm}$ in diameter with a double lipid envelope and glycoprotein capsomers that surrounds the nucleocapsid sometimes herring-bone-like shape (Lamb et al., 2005).

Its genome varies from 13-19 $\mathrm{kb}$ and contains 6-10 genes encoding more than 12 different proteins. All Paramyxoviridae family members codify the nucleoprotein
$(\mathrm{N})$, phosphoprotein $(\mathrm{P})$, matrix protein $(\mathrm{M})$, fusion $(\mathrm{F})$, hemagglutinin $(\mathrm{H})$, hemagglutinin-neuraminidase $(\mathrm{HN})$, glycoprotein (G) and polymerase (L) (Lamb \& Parks, 2007; Samal, 2008).

The avian paramyxoviruses were classified in 10 serotypes (APMV 1-10) by hemagglutination inhibition and neuraminidase inhibition techniques (Alexander et al., 1983; Miller et al., 2010).

The serotype 1 (APMV-1) includes all strains of Newcastle disease. The pathogenic variability of these strains grouped them in three pathotypes, highly virulent (velogenic) which causes severe respiratory disease, moderately virulent (mesogenic) inducing mild disease and non-pathogenic (lentogenic) with inapparent infection (Alexander, 1997). According to this author in chickens the virulence of these strains cause severe disease.

\footnotetext{
* Laboratory of Electron Microscopy, Biological Institute of São Paulo, Brazil.

** Adolfo Lutz Institute, São Paulo, Brazil.

*** Tiete Ecological Park, São Paulo, Brazil.
} 
In wild or captive birds, as galliformes, columbiformes, piciformes, anseriformes, gruiformes, passeriformes and psittaciformes, the serotype 1 (APMV1) was observed (Alexander, 1988). Several clinical signs and symptoms were described, such as depression, diarrhea, anorexia, ruffled feathers, oculonasal discharge, conjunctivitis, dyspnea, ataxia, muscle tremors, abnormal movements, torticollis, paralysis and death in parrot, macaw, cockatiel, canure (Alexander, 1988; Panigrah et al.; 1993; Grund et al., 2002; Clavijo et al., 2000; Greenacre et al., 2005), house sparrow (Khalaffala et al., 1990a, b) and dove (Terregino et al., 2003; Marlie \& Vangevogel, 2006).

Other authors have demonstrated the occurrence of serotype 1 (APMV-1) in human with symptoms of the conjunctivitis and sinusitis. Moreover, the occurrence of a fatal human case due to pneumonia has proven that this disease is an important zoonosis (Greenacre; Goebel et al., 2007).

In contrast, little is known about the potential pathogenic of APMV-2 to APMV-10 serotypes in captive or wild birds (Bankowski et al., 1968; Alexander et al., 1982; Zhang et al., 2006; Miller et al.).

It was reported that in passerines and psittacines, the serotype 2 (APMV-2) frequently occurs triggering mild respiratory disease or high limiting, severe pneumonia, and diarrhea in passerines (Ritchie \& Carter, 1995; Zhang et al.) and weakness, weight loss, pneumonia, tracheitis, diarrhea with high mortality in psittacines (Collins et al., 1975, Ritchie).

In addition, the serotype 3 (APMV-3) affects psittacines more frequently than passerines (Beck et al., 2003). The disease is characterized by acute or chronic pancreatitis, torticollis, circling, opisthotonus, ataxia, steatorrhea, vomiting, diarrhea and high mortality in house sparrow (Stallknecht et al.) and in parakeet and finch (Ritchie; Shivaprasad, 1998; Shihtmanter et al., 1998; Kaleta, 1999; Beck et al.; Jung et al., 2009).

It was observed the occurrence of serotype 4 (APMV4) in free-living birds, such as duck (Alexander et al., 1979; Gough \& Alexander, 1984; Stallknecht et al.; Maldonado et al., 1995; Stanislawek et al., 2002; Jeon et al., 2008; Rosseel et al., 2011), goose and coot (Maldonado et al.) and the serotype 5 (APMV-5) in parakeet, leading to depression, dyspnea, torticollis, vomiting, diarrhea and death (Mustaffabab Jee, 1974; Nerome et al., 1978; Gough et al., 1993).

The serotypes 6 (APMV-6) and 7 (APMV-7) were isolated from healthy free-living birds such as duck
(Stallknecht et al.; Maldonado et al.; Stanislawek et al.; Warke et al., 2008; Rosseel et al.), goose, grey heron, blackheaded gull, coot, spoonbill, house sparrow (Maldonado et al.), turkey with respiratory disease associated to egg production drop (Saif et al., 1997) and ostrich with enteritis (Wollcook et al., 1996).

As for the serotypes 8 (APMV-8) and 9 (APMV-9), these also were detected in free-living species, such as duck (Yamane et al.; 1982; Stallknecht et al.; Maldonado et al.; Capua et al., 2004) goose, grey heron, crane, greater flamingo, coot, spoonbill, house sparrow, hoopoe (Maldonado et al.) and the serotype 10 (APMV-10) in penguins (Miller et al.; Fornells et al., 2012).

The transmission electron microscopy technique has been useful for identification of unknown viruses, enabling rapid identification of these agents (Gentile\& Gelderblom, 2005; Roingeard, 2008).

The aim of this study was to investigate the presence of viral agents in stool and small intestine samples of the 1647 captive and wild birds, using negative staining and resin embedding techniques.

\section{MATERIAL AND METHOD}

Description of the cases. In the period 2000 to 2011, a total of 1647 stool and fragments of the small intestine samples of various species of birds were sent to the Microscopy Laboratory of the Biological Institute of São Paulo for diagnosis of viral agents. Of these, 294 (17.8\%) were positive for paramyxoviruses of which, 152 were Passeriformes, 105 Psitaciformes, 30 Columbiformes, 1 Apodiforme, 2 Piciformes, 2 Charadriformes, 1 Caprimulgiforme and 1 Musofagiforme. The Passeriforme order included, 1 helmeted manakin (Anthilophia Galeata), 1 common waxbill (Estrilda astrild), 6 doublecollared seedeater (Sporophila caerulescens), 3 Turdus sp., 2 Thraupis sp, 11 rufous-bellied thrush (Turdus rufiventris), 1 great kiskadee (Pitangus sulphuratus), 1 bananaquit (Coereba flaveola), 12 bay-winged cowbird (Gnorimopsar chopi), 1 grey monjita (Xolmis cinerea), 1 surucua trogon (Trogon surrucura), 11 green-winged saltator (Saltator similis), 13 common canary (Serinus canaria), 2 wild canary (Serinus canarius), 10 saffron finch (Sicalis flaveola), 2 brazilian tanager (Ramphocelus bresilius), 3 campo troupial (Icterus jamacaii), 21 greatbilled seed-finch (Sporophila maximiliani), 1 red-crested finch (Lanio cucullatus), 4 ultramarine grosbeak (Cyanocompsa brissonii), 1 lined seedeater (Sporophila 
lineola), 1 variable oriole (Icterus pyrrhopterus), 4 sevencolored tanager (Tangara fastuosa), 10 hooded siskin (Carduelis magelanica), 1 red siskin (Carduelis cucullata), 1 white-naped jay (Cyanocorax cyanopogon), 1 brassy breasted tanager (Tangara desmaresti), 5 Carduelis sp., 1 swallow tanager (Tersina viridis), 1 buffy-fronted seedeater (Sporophila frontalis), 1 gilt-edgerd tanager (Tangara cyanoventris), 5 unidentified canaries and 16 unindentified Passeriformes. Regarding the Psitaciforme order, we found 2 scaly-headed parrot (Pionus maximiliani), 27 blue-fronted parrot (Amazona aestiva), 1 gian-red macaw (Ara chloroptera), 1 red-and-green macaw (Ara chloropterus), 4 blue-and-yellow macaw (Ara ararauna), 2 hyacinth macaw (Anadorhynchus hyacinhinus), 3 vinaceous parrot (Amazona vinacea), 3 Aratinga sp., 4 Agapornis sp., 4 Cacatua sp., 4 grey-parrot (Psittacus erithacus), 22 cockatiel (Nymphicus hollandicus), 2 budgerigar (Melopsittacus undulatus), 1 salmon-crested cockatoo (Cacatua moluccensis), 1 Ecletus sp., 1 eclectus parrot (Ecletus roratus), 2 peach-fronted conure (Aratinga aurea), 1 military macaw (Ara militaris), 1 plain parakeet (Brotogeris tirica), 1 orange-winged parrot (Amazona amazonica), 1 rose-ringed parakeet (Psittacula krameri), 1 Pyrrhura sp., 1 red-shouldered macaw (Diopsittaca nobilis), 3 golden canure (Aratinga guarouba), 1 blue-winged macaw (Ara maracanã), 1 unidentified macaw, 5 unindentified and 5 unmarked parrots. The Columbiforme order consisted of 29 rock pigeon (Columba livia) and 1 ruddy ground-dove (Columbina talpacoti), Piciforme order, 1 blond-crested woodpecker (Celeus flavescens) and 1 campo flicker (Colaptes campestris), Apodiforme order, 1 swallow-tailed hummngbird (Eupetomena macroura), Charadriforme order, 1 black skimmer (Rynchops niger) and 1 southern lapwing (Vanellus chilensis), Caprimulgiforme order, 1 nacunda nighthawk (Chordeiles nacunda) and Musofagiforme order 1 violet turaco (Musophaga violacea).

Negative staining technique (rapid preparation). In the negative staining technique, stool and small intestine fragments samples were suspended in phosphate buffer 0.1 M, pH 7.0. Drops of the obtained suspensions were placed in contact with metallic copper grids with carbon stabilized supporting film of $0.5 \%$ collodion in amyl acetate. Next, the grids were drained with filter paper and negatively stained at $2 \%$ ammonium molybdate, $\mathrm{pH} 5.0$ (Brenner \& Horne, 1959; Hayat \& Miller, 1990; Madeley, 1997).

Resin embedding technique. Small intestine fragments samples were fixed in $2.5 \%$ glutaraldehyde in $0.1 \mathrm{M}$, pH7.0 phosphate buffer and pos-fixed in $1 \%$ osmium tetroxide in the same buffer. After dehydration in cetonic series, the fragments were embedded in Spurr resin (GonzálezSantander, 1969; Luft, 1961). Ultrathin sections were cut on the LKB ultratome and mounted on copper grids. The sections were contrasted with uranyl acetate-lead citrate (Watson, 1958; Reinolds, 1963).

The processed samples were analyzed in a Philips EM 208 electron microscope, at $80 \mathrm{kV}$.

\section{RESULTS}

Signs and symptoms. The most common clinical signs and symptoms presented by the studied birds were apathy, anorexia, weight loss, prostration, diarrhea, polyuria, conjunctivitis, periocular edema, ruffled feathers, sneezing, dyspnea, pneumonia, incoordination, lack of balance, tremors, thick saliva, proventricular dilatation, crop emptying problems, leukopenia and death. Some other symptomatic and asymptomatic birds had sudden death.

Negative staining technique (rapid preparation). On the transmission electron microscopy paramyxovirus particles, pleomorphic, roughly spherical or filamentous, measuring 100 to $500 \mathrm{~nm}$ of diameter containing an envelope covered by spikes (Figs.1,3, arrow), with characteristic helical herring-bone-like nucleocapsid, measuring 15 to $20 \mathrm{~nm}$ in diameter (Fig. 2, arrow) were visualized in stool and small intestine samples of the $294(17,8 \%)$ birds.

Resin embedding technique. Ultrathin sections of the small intestine fragments positively stained by combination of uranyl acetate and lead citrate, revealed the presence of

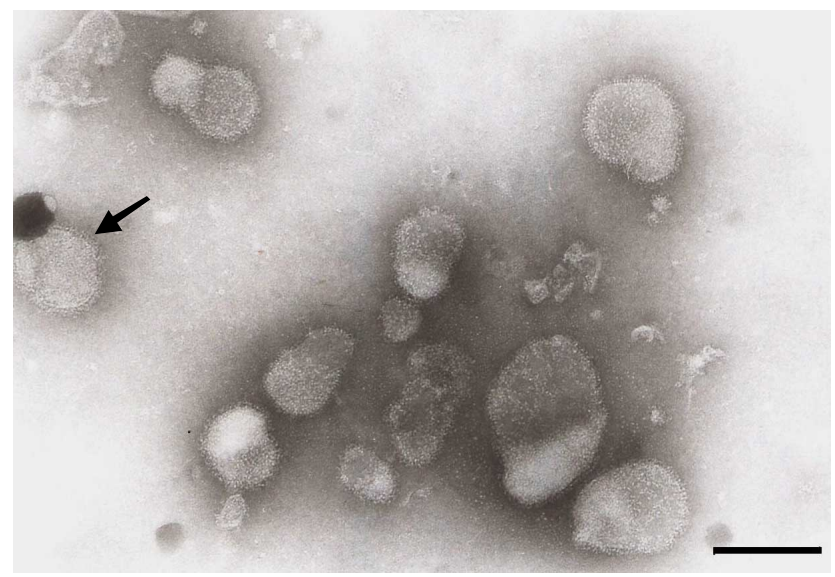

Fig. 1. Negatively stained paramyxovirus particles, pleomorphic, roughly spherical, containing an envelope covered by spikes in small intestine of saffron finch (Sicalis flaveola) (arrow). Bar:180 nm. 


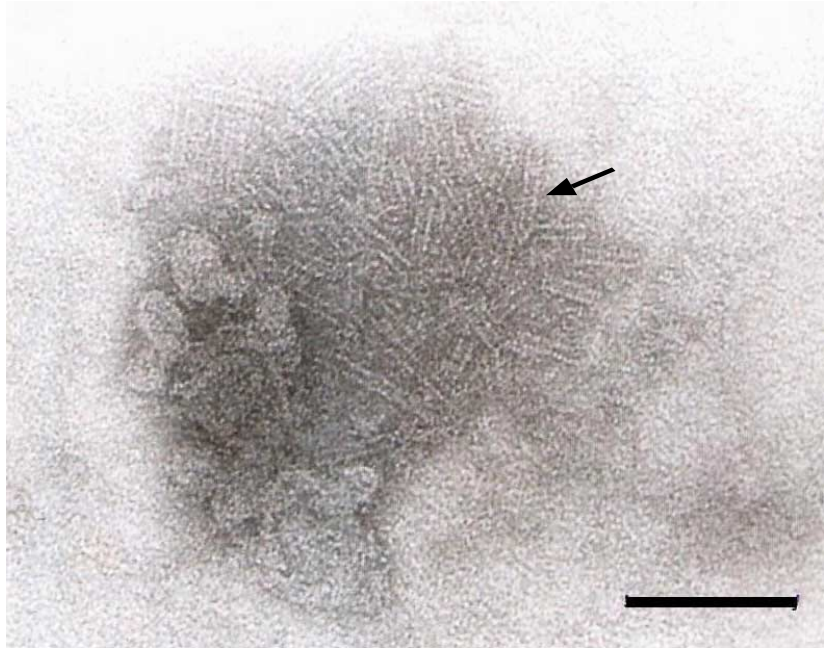

Fig. 2. Negatively stained paramyxovirus nucleocapsids showing pattern "herringbone" (arrow). Bar: $120 \mathrm{~nm}$.

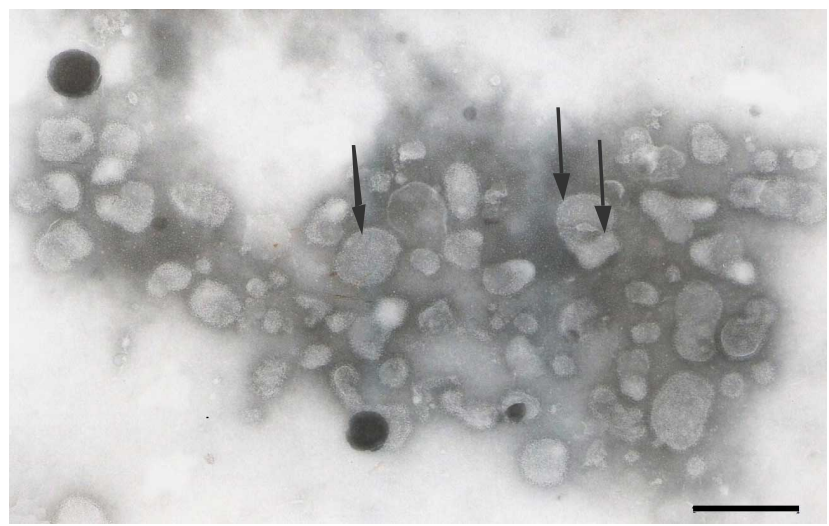

Fig. 3. Negatively stained paramyxovirus particles, pleomorphic, roughly spherical, containing an envelope covered by spikes in small intestine of peach-fronted conure (Aratinga aurea) (arrow). Bar: $260 \mathrm{~nm}$.

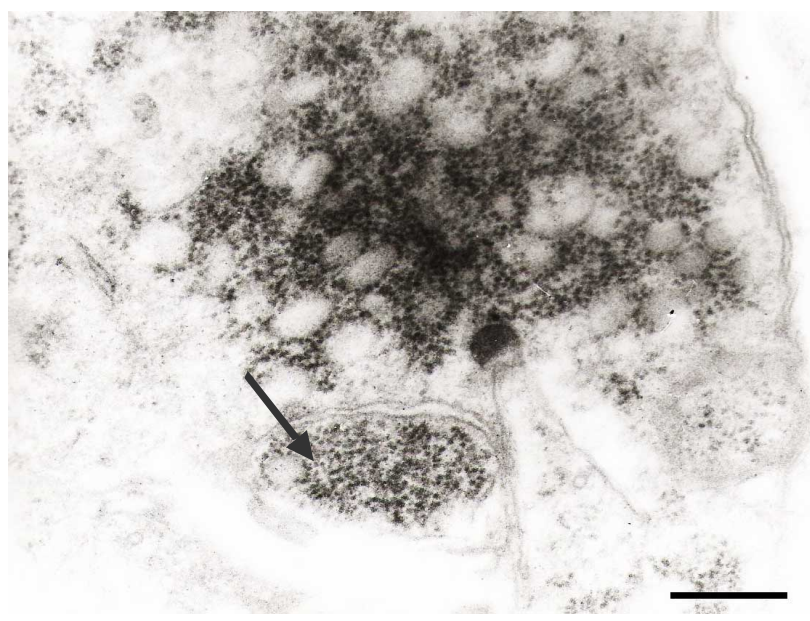

Fig. 4. Ultrathin section of the small intestine fragments of the hooded siskin (Carduelis maggelanica).Intracytoplasmic inclusion containing viral nucleocapsids (arrow). Bar: $380 \mathrm{~nm}$. intracytoplasmic granular amorphous inclusions surrounded by membrane and containing viral nucleocapsid, measuring 10-14 nm in diameter (Figs. 4, 5, arrow). Intranuclear inclusions containing viral nucleocapsid were also visualized (Fig.6, big arrow). The nuclei showed a marginalized chromatin (Fig. 6, minor arrow).

Immature intracytoplasmatic particles, budding from cell membranes (Fig.7, big arrow) and pleomorphic (Fig.7, minor arrow), spherical (Fig. 7, blue arrow) and tubular viral particles (Fig. 7, gray arrow) containing nucleocapsid strands were seen in the cytoplasm. The complete particles measured up to $170 \mathrm{~nm}$ in diameter.

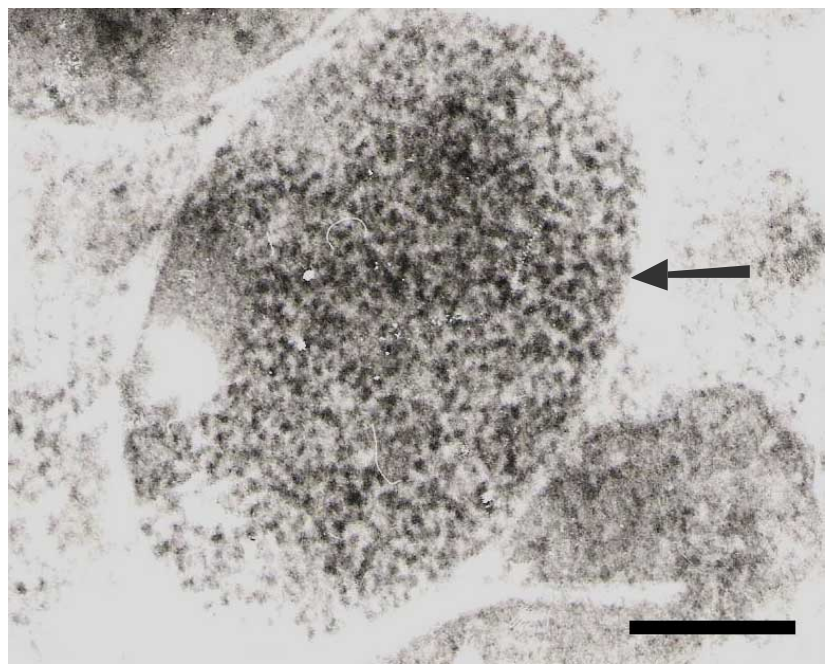

Fig. 5. Ultrathin section of the small intestine fragments of the saffron finch (Sicalis flaveola). Intracytoplasmic inclusion containing viral helical nucleocapsids measuring $10 \mathrm{~nm}$ in diameter (arrow). Bar: $240 \mathrm{~nm}$.

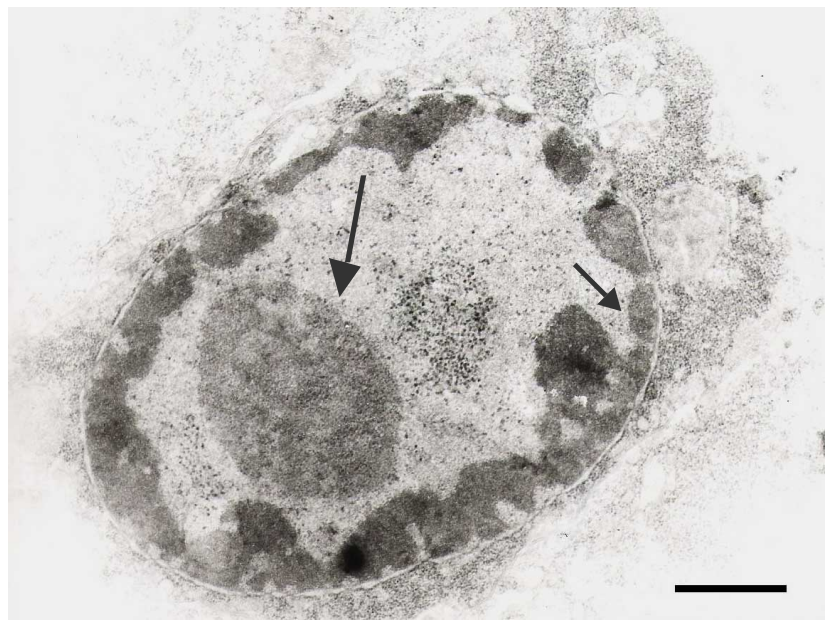

Fig. 6. Ultrathin section of the small intestine fragments of the Carduelis maggelanica, showing intranuclear inclusions containing viral nucleocapsids (big arrow) and marginalized chromatin (minor arrow). Bar: $960 \mathrm{~nm}$. 


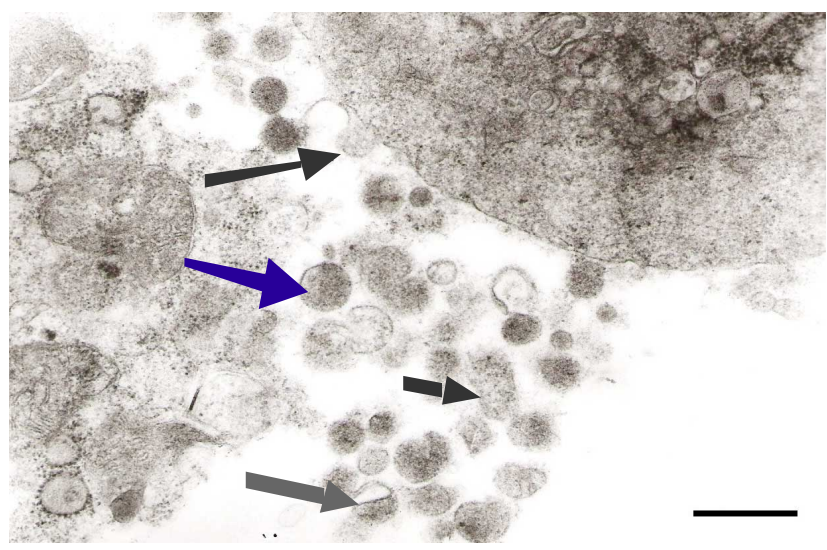

Fig. 7. Ultrathin section of the small intestine fragments of the saffron finch (Sicalis flaveola). Observe Immature intracytoplasmatic particles, budding from cell membranes (big arrow) and pleomorphic (minor arrow), spherical (blue arrow) and tubular viral particles containing nucleocapsid strands (gray arrow). Bar: $340 \mathrm{~nm}$.

\section{DISCUSSION}

In this study the samples of the 294 (17.8\%) avian species analyzed by negative staining technique showed pleomorphic paramyxovirus particles, roughly spherical or filamentous, measuring 100 to $500 \mathrm{~nm}$ of diameter containing an envelope covered by spikes and characteristic helical herring-bone-like nucleocapsid with 15 to $20 \mathrm{~nm}$ in diameter.

Several authors using the same technique, described the presence of particles with morphological characteristics similar in other avian species, as budgerigar (Nerome et al.), dove (Alexander et al., 1981; Catroxo et al., 2011), ringedteal (Gough \& Alexander), parrot and parakeet (Steffens, 1998, Grund et al.), yacinth macaw, rusty collared seedeater, red cowled cardinal, curl crested and peach fronted parakeet (Catroxo et al., 2000), duck (Chang et al., 2001), cockatiel (Clavijo et al.), goose (Jinding et al., 2005), gouldian finch (Zhang et al.), owl (Catroxo et al., 2010) and penguin (Miller et al.; Fornells et al.).

The presence of intracytoplasmatic and intranuclear inclusions, surrounded by a membrane and containing viral nucleocapsid are in accordance with other authors who used the resin embedding technique (Mannl et al., 1987; Granzow et al., 1999; Jacobson et al., 2001).

In addition, the observation of intracytoplasmatic immature particles budding from cell membranes and pleomorphic spherical and tubular viral particles containing nucleocapsid strands corroborate with literature findings (Mannl et al.; Granzow et al.; Jacobson et al.).
The birds had symptoms of enteric, respiratory and neurological disorders, being the most common apathy, anorexia, weight loss, prostration, diarrhea, polyuria, conjunctivitis, periocular edema, ruffled feathers, sneezing, dyspnea, pneumonia, incoordination, lack of balance, tremors, thick salivation, proventricular dilatation, crop emptying difficulty, leukopenia and death.

Similar symptoms were observed during infection by serotype 1 (APMV-1) of Newcastle disease, in species such as parrot, macaw, cockatiel, canure (Alexander, 1988; Panigrah et al., 1993, Grund et al.; Clavijo et al.; Greenacre et al.), house sparrow (Khalaffala et al., 1990a,b) dove (Terregino et al.; Marlie \& Vangevogel), and in infection by serotype 3 (APMV-3) in passerines and psittacines such as house sparrow (Stallknecht et al.) parakeet and finch (Ritchie \& Carter; Beck et al.). In infection by the serotype 2 (APMV-2) enteric and respiratory symptoms were observed in parrots (Collins et al.) parakeet and finch (Ritchie; Zhang et al.).

In three of the studied birds, 1 common canary (Serinus canaria), 1 cockatiel (Nymphicus hollandicus) and 1 peach-fronted conure (Aratinga aurea) dilatation of the proventriculus were observed. Grund et al. isolated particles of the paramyxovirus serotype 1 of the spinal cord of parrots with proventricular dilatation syndrome, but this interrelationship has not been confirmed.

Some species such as great kiskadee (Pitangus sulphuratus), (Thraupis sp.), bananaquit (Coereba flaveola), red siskin (Carduelis cucullatus) and blue-fronted parrot (Amazona aestiva) which were asymptomatic, had sudden death. According to Ritchie et al. passerines with velogenic or mesogenic pathotype of Newcastle disease are more susceptible to absence of symptoms and sudden death. Some species become ill while others can carry the virus asymptomatically (OIE, 2009).

Canaries and minahs which were infected by serotype 1 (APMV-1) showed gradual mortality (Alexander, 1988).

In addition, serotypes 4 (AMPV-4), 6 (APMV-6), 8 (APMV-8) and 9 (APMV-9) were isolated from several species of healthy free-living birds as duck (Yamane et al.; Stallknecht et al.; Capua et al.), goose, grey heron, crane, black-headed, gull, greater flamingo, coot, spoonbill, house sparrow and hoopoe (Maldonado et al.).

We concluded that paramyxoviruses are present in most breeding and ecological parks may cause economic losses and harm to nature. 
Studies on the typification of the different serotypes (APMV-1-10) are needed to clarify the types of paramyxoviruses circulating in our environment and also contribute to the future development of vaccines against these agents agreement with the view of the Subbiah et al. (2010).
The used techniques of transmission electron microscopy allowed the rapid visualization of paramyxovirus particles, collaborating in the control of the diseases in breeders and breeding through the implementation of prophylactic measures, preventing loss and damage and preserving the endangered free living species.

CATROXO, M.H.B.; MARTINS, A.M.C.P.F.; PETRELlA, S.; MILANELO, L.; ASCHAR, M.; SOUZA, F.; NASTARI, B.D.B.; SOUZA, R.B. Paramixovirus aviario. Detección por técnicas de microscopia electrónica de transmisión. Int. J. Morphol., 30(2):723730, 2012.

RESUMEN: Las enfermedades causadas por paramixovirus (APMV) ocurren mundialmente, tanto en aves de corral, en aquellas en vida libre o en cautiverio, lo que demuestra la importancia económica y ecológica de estos virus. El paramixovirus aviario pertenece a la familia Paramyxoviridae, subfamilia Paramyxovirinae y género Avulavirus. Durante el periodo de 2000 a 2011 , muestras de heces y fragmentos del intestino delgado de 1647 especies de aves han sido enviados al Laboratorio de Microscopía Electrónica, Instituto Biológico de São Paulo, para el diagnóstico de agentes virales. Las heces y fragmentos del intestino delgado, se procesaron por las técnicas de contraste negativo (preparación rápida) y la inclusión en resina. Al microscopio electrónico de transmisión mediante la técnica de contraste negativo se visualizaron en muestras de 294 aves, partículas de paramixovirus, pleomórficas, más o menos esféricas o filamentosas, de 100 a $500 \mathrm{~nm}$ de diámetro que contenían un sobre cubierto por púas que presentaban característica helicoidal, con nucleocapside tipo espiga, midiendo de 15 a $20 \mathrm{~nm}$ de diámetro. Secciones ultrafinas de los fragmentos del intestino delgado, revelaron en el citoplasma la presencia de inclusiones granulares amorfas rodeadas por una membrana, contiendo nucleocapside viral midiendo de 10-14 nm de diámetro, partículas inmaduras brotando de las membranas celulares, partículas virales tubulares, esféricas o pleomórficas que contenían filamentos nucleocapside. Estas partículas completas alcanzaban a los $170 \mathrm{~nm}$ de diámetro. Fueron observadas también, inclusiones intranucleares contiendo nucleocapside viral. Los núcleos mostraron una cromatina marginal.

PALABRAS CLAVE: Paramoxyvirus; Aviario; Microscopía Electrónica de Transmisión.

\section{REFERENCES}

Alexander, D.J.; Aymard, M.; Kessler, N. \& Collins, M.S. Antigenic and structural relationships between avian paramyxoviruses isolated from ducks in Hong Kong and Mississippi, USA. $J$. Gen.Virol., 44:839-42, 1979.

Alexander, D. J.; Hinshaw, V.S. \& Collins, M.S. Characterization of viruses from doves representing a new serotype of avian paramyxoviruses. Arch. Virol., 68:265-9, 1981.

Alexander, D.J.; Allan, W.H.; Parsons, G. \& Collins, M.S. Identification of paramyxoviruses isolated from birds dying in quarantine in Great Britain during 1980 to 1981. Vet. Rec., 111:571-4, 1982.

Alexander, D.J.; Hinshaw, V.S.; Collins, M.S. \& Yamane, N. Characterization of viruses which represent further distinct serotypes (PMV-8 and PMV-9) of avian paramyxoviruses. Arch. Virol., 78:29-36, 1983.

Alexander, D. J. Newcastle disease virus - an avian paramyxovirus structure. In: Alexander, D.J. Newcastle Disease, Kluwer Academic Publishers, Boston, USA, 1988. pp. 11-22.

Alexander, D. J. Newcastle disease and other avian paramyxoviridae infections. In: Calnek, B. W., H. J. Barnes, C. W. Beard, L. R. McDougald and Y. M. Saif (eds), Diseases of Poultry, 10th Ed., Iowa State Univ. Press, Ames, Iowa, USA, 1997. p. 541-569.
Bankowski, R.A.; Conrad, R.D. \& Reinolds, B.; Avian influenza A and paramyxoviruses complicating respiratory disease diagnosis in poultry. Avian Dis., 12:259-78, 1968.

Beck, I.; Gerlach, H.; Burkhardt, E. \& Kaleta, E.F. Investigation fo several selected adjuvants regarding their efficacy and side for the production of a vaccine for parakeets to prevent a disease caused by a paramyxovirus type 3. Vaccine, 21:1006-22, 2003.

Brenner, S. \& Horne, R. W. A negative staining method for high resolution electron microscopy of viruses. Biochem. Biophys. Acta., 34:103, 1959.

Capua, I.; De Nardi, R.; Beato, M.S.; Terregino, C.; Scremin, M. \& Guberti, V. Isolation of an avian paramyxovirus type 9 from migratory waterfowl in Italy. Vet. Rec., 155:6, 2004.

Catroxo, M.H.B.; Silva, J.C.R.; Menezes, A.C.; Curi, N.A. \& Schmich, H. Presença de partículas semelhantes a corona e paramixovírus em fezes de aves silvestres (Passeriformes $e$ Psittaciformes). A Ornitologia no Brasil - Pesquisa Atual e Perspectivas. $1^{\text {a }}$ ed. Rio de Janeiro, RJ, v.1, p.161-9, 2000.

Catroxo, M. H. B.; Taniguchi, D. L.; Melo, N. A.; Milanelo, L.; Petrella, S.; Alves, M.; Martins, A. M. C. R. P. F. \& Rebouças, M. M. Viral research in Brazilian owls (Tyto alba and Rhinoptynx clamator) by transmission electron microscopy. Int. J. Morphol., 28(2):627-36, 2010. 
Catroxo, M. H. B. ; Martins, A. M. C. R. P. F.; Petrella, S.; Curi, N. A. \& Melo, N.A. Research of viral agents in free-living pigeon Feces (Columba livia) in the city of São Paulo, SP, Brazil, for transmission electron microscopy. Int. J. Morphol., 29(2):628$635,2011$.

Chang, P.C.; Hsieh, M.L.; Shien, J.H.; Graham, D.A.; Lee, M.S. \& Shied, H.K. Complete nucleotide sequence of avian paramyxovirus type 6 isolated from ducks. J. Gen. Virol., 82: 2157-68, 2001.

Clavijo, A.; Robinson, Y.; Booth, T. \& Munroe, F. Velogenic Newcastle disease in imported caged birds. Can. Vet. J., 41:4046, 2000 .

Collins, D.F.; Fitton, J.; Alexander, D.J.; Harkness, J.W. \& Pattison, M. Preliminary characterization of a paramyxovirus isolated from a parrot. Res. Vet. Sci., 19:219-21, 1975.

Fornells, L.A.; Silva, T.F.; Bianchi, I.; Travassos, C.E.; Liberal, M.H.; Andrade, C.M.; Petrucci, M.P.; Veiga, V.F.; Vaslin, M.F. \& Couceiro, J.N. Detection of paramyxoviruses in Magellanic penguins (Spheniscus magellanicus) on the Brazilian tropical coast. Vet. Microbiol., 156(3-4):429-33, 2012.

Gentile, M. \& Gelderblom, H.R. Rapid viral diagnosis: role of electron microscopy. New Microbiol., 28(1):1-12, 2005.

Goebel, S.J.; Taylor, J.; Barr, B.C.; Kiehn, T.E.; Castro-Malaspina, H.R.C.; Hedvat, C.V.; Rush-Wilson, K.A.; Kelly, C.D.; Davis, S.W.; Samsonoff, W.A.; Hurst, K.R. \& Behr, M.J.; Masters, P.S. Isolation of paramyxovirus 1 from a patient with a lethal case of pneumonia. J. Virol., 81(22):12709-14, 2007.

Gonzales-Santander, R. Técnicas de microscopia eletrônica en biología. Madrid, Ed. Aguilar, 1969. 666 p.

Gough, R.E. \& Alexander, D.J. Avian paramyxovirus type 4 isolated from a ringed teal (Calonetta leucophrys). Vet, Rec., 115:653, 1984.

Gough, R.E.; Manvell R.J.; Drury, S.E.; Naylor, P.F.; Spackman, D. \& Cooke, S.W. Deaths in budgerigars associated with a paramyxovirus-like agent. Vet. Rec., 133(5):123, 1993.

Granzow, H.; Weiland, F.; Mundt, E.; Kollner, B.K. \& Werner, O. Intranuclear inclusions in cells infected with Newcastle disease virus. J. Vet. Med.,46(6):411-21, 1999.

Greenacre, C.B. Viral diseases of companion birds. Vet. Clin. Exot. Anim., 8: 85-105, 2005.

Grund, C.H.; Werner, O.; Gelderblom, H.R.; Grimm, F. \& Kosters, J. Avian Paramyxovirus serotype 1 isolates from the spinal cord of parrots display a very low virulence. J. Vet. Med. B., 49:445-51, 2002.

Hayat, M. A. \& Miller, S. E. Negative Staining. Mc. Graw-Hill Publ. Company., 1990. 235p.

ICTV, Virus Taxonomy. 2011. Disponível em: http:// www.ictvonline.org/virusTaxonomy.asp.
Jacobson, E.R.; Origgi, F.; Pessier, A.P.; Lamirande, E.W.; Walker, I.; Whitaker, B.; Stalis, I.H.; Nordhausen, R.; Owens, J.W.; Nichols, D.K.; Heard, D. \& Bruce Homer, B. Paramyxovirus infection in caiman lizards (Draecena guianensis). J. Vet. Diagn. Invest., 13:143-51, 2001.

Jeon, W.J.; Lee, E.K.; Kwon, J.H. \& Choi, K.S. Full-length genome sequence of avian paramyxovirus type 4 isolated from a mallard duck. Virus Genes., 37:342-50, 2008.

Jinding, C.; Ming, L.; Tao, R. \& Chaoan, X. A goose-sourced isolated from Southern China. Avian Dis., 49(1):170-3, 2005.

Jung, A.; Grund, C.; Muller, I. \& Rautenschlein, S. Avian paramyxovirus serotype 3 infection in Neopsephotus, Cyanoramphus, and Neophema species. J. Avian. Med. Surg., 23:205-8, 2009.

Kaleta, E.F. \& Broden, M. Detection, significance and control of paramyxoviruses in birds. Tierarztl Prax.,22(4):329-33, 1994.

Kaleta, E.F. Paramyxovirus-3-Infektion der Psittaziden. In: Kaleta EF, Krautwald-Junghanns ME, editors. Kompendium der Ziervogelkrankheiten. Hannover: Schlütersche; 1999. p. 287-8.

Khalafalla, A.I.; Nayil, A.A.; Nimir, A.H. \& Hajer, I. Role of some passeriformes birds in transmission of Newcastle disease I. Susceptibility of some wild birds of Sudan to Newcastlw disease virus. Bull. An. Health Prod. Africa., 38(1):45-9, 1990a.

Khalafalla, A.I.; Hajer, I. \& Nimir, A.H. Role of some passeriformes birds in transmission of Newcastle diseaseII. Pathogenesis for Newcastle disease virus in Sudan house sparrows (Passer domesticus arborius). Bull. An. Health Prod. África., 38(1):514, 1990b.

Lamb, R.A.; Collins, P.L.; Kolakofsky, D.; Melero, J.A.; Nagai, Y.; Oldstone, M.B.A.; Pringle, C.R. \& Rima, BK. Family Paramyxoviridae. In: Fauquet, C.M., ed. Virus Taxonomy: The Classification and Nomenclature of Viruses. The Eighth Report of the International Committee in Taxonomy of Viruses. Eds. Press EA, 2005.

Lamb, R. \& Parks, G., In: Paramyxoviridae: the viruses and their replication. In: Knipe, D.M.; Howley, P.M.; Griffin, D.E.; Lam, R.A.; Martin, M.A.; Roizman, B.; Straus, S.E. Eds. Lippincott Williams \& Wilkins, Philadelphia, 2007. pp. 1449-96.

Luft, J. A. Improvements in an epoxy resin embedding methods. $J$. Biophys. Biochem. Cytol., 9:409-14, 1961.

Madeley, C. R. Electron microscopy and virus diagnosis. J. Clin. Pathol., 50:454-6, 1997.

Maldonado, A.; Arenas, .A.; Tarradas, M.C.; Luque, I.; Astorga, R.; Perea, J.A. \& Miranda, A. Serological survey for avian paramyxoviruses from wildfowl in aquatic habitats in Andalusia. J. Wildl. Dis., 31:66-9, 1995.

Mannl, A.; Gerlach, H. \& Leipold, R. Neuropathic gastric dilatation in psittaciformes. Avian Dis., 31(1):214-21, 1987. 
Marlier, D. \& Vindevogel, H. Viral infections in pigeons. Vet. J., $172: 40-51,2006$.

Miller, P.J.; Afonso, C.L.; Spackman, E.; Scott, M.A.; Pedersen, J.C.; Senne, D.A.; Brown, J.D.; Fuller, C.M.; Uhart, M.M.; Karesh, W.B.; Brown, I.H.; Alexander, D.J. \& Swayne, D.E. Evidence for a New Avian Paramyxovirus Serotype 10 Detected in Rockhopper Penguins from the Falkland Islands J. Virol., 84(21):11496-504, 2010.

Mustaffa-Babjee, A.; Spradbrow, P.B. \& Samuel, J.L. A pathogenic paramyxovirus from a budgerigar (Melopsittacus undulatus). Avian Dis., 18:226-30, 1974.

Nerome, K.; Nakayama, M.; Ishida, M. \& Fukumi, H. Isolation of a new avian paramyxovirus from budgerigar (Melopsittacus undulatus). J. Gen. Virol., 38:293-301, 1978.

OIE. Manual of Diagnostic Tests \& Vaccines for Terrestrial Animal. In: Newcastle disease. $7^{\text {a }}$. Ed. France, Paris, 2009. pp. 576-89.

Panigrahy, B.; Senne, D.A.; Pearson J.E.; Mixson M.A. \& Cassidy D.R. Occurrence of velogenic viscerotropic Newcastle disease in pet and exotic birds in 1991. Avian Dis., 37:254-28, 1993.

Reinolds, E.S. The use of lead citrate at high $\mathrm{pH}$ as an electron-opaque stain in electron microscopy. J. Cell. Biol., 17:208-12, 1963.

Ritchie, B.W. \& Carter, K. Avian viruses: Function and control. Lake Worth, Florida, Ed. Publishing Incorporated, 1995. pp.285-311.

Ritchie, B.W.; Harrison, G.J. \& Harrison, L.R. Avian Medicine: Principles and application. Florida, Ed. Wingers Publishing Inc., 1994. pp.865-74.

Roingeard, P. Viral detection by electron microscopy: past, present and future. Biol. Cell.,100:491-501, 2008.

Rosseel, T.; Lambrecht, B.; Vandenbussche, F.; Van den Berg , T. \& Van Borm, S. Identification and complete genome sequencing of paramyxoviruses in mallard ducks (Anas platyrhynchos) using random access amplification and next generation sequencing technologies. Virol. J., 8(463):1-11, 2011.

Saif, Y.M.; Mohan, R.; Ward, L.; Senne, D.A.; Panigrahy, B. \& Dearth, R.N. Natural and experimental infection of turkeys with avian paramyxovirus-7. Avian Dis., 41:326-9, 1997.

Samal, S.K. Paramyxoviruses of Animals. Encyclopedia of Virology Third edition. 2008, 4:40-47.

Shihtmanter, E.; Weisman, Y.; Lublin, A.; Mahani, S.; Panshin, A. \& Lipkind, M. Isolation of avian serotype 3 paramyxoviruses from imported caged birds in Israel. Avian Dis., 42:829-31, 1998.

Shivaprasad HL. An Overview of paramyxovirus 3 (PMV-3) infection in psittacines and passerines. In: AAV Proceedings; 1998. p. 147-49.

Stanislawek, W.L.; Wilks, C.R.; Meers, J.; Horner, G.W.; Alexander, D.J.; Manvell, R.J.; Kattenbelt, J.A. \& Gould,A.R. Avian paramyxoviruses and influenza viruses isolated from mallard ducks (Anas platyrhynchos) in New Zealand. Arch. Virol., 147:1287-302, 2002.

Stallknecht, D.E.; Senne, D.A.; Zwank, P.J.; Shane, S.M. \& Kearney, M.T. Avian paramyxoviruses from migrating and resident ducks in coastal Louisiana. J. Wildl. Dis., 27:123-8, 1991.

Steffens, W.L. Use of Transmission Electron Microscopy for Viral Diagnosis in Psittacine Birds. IVCVM, 1998.

Subbiah, M.; Nayak, S.; Collins, P.L. \& Samal, S.K. Complete genome sequences of avian paramyxovirus serotype 2 (APMV-2) strains Bangor, England and Kenya: Evidence for the existence of subgroups within serotype 2. Virus Res., 152(1-2):85-95, 2010.

Terregino, C.; Cattoli, G.; Grossele, B.; Bertoli, E.; E. Tisato, E. \& Capua, I. Characterization of Newcastle disease virus isolates obtained from Eurasian collared doves (Streptopelia decaocto) in Italy. Avian Pathol., 32:63-8, 2003.

Warke, A.; Stallknecht, D.; Williams, S.M.; Pritchard, N. \& Mundt, E. Comparative study on the pathogenicity and immunogenicity of wild bird isolates of avian paramyxovirus 2, 4, and 6 in chickens. Avian Pathol., 37:429-34, 2008.

Watson, M. L. Staining of tissue sections for electron microscopy with heavy metals. J. Biophyis. Biochem. Cytol., 4:475-78, 1958.

Woolcock, P.R.; Moore, J.D.; McFarland, M.D. \& Panigrahy, B. Isolation of paramyxovirus serotype 7 from ostriches (Struthio camelus). Avian Dis., 40:945-9, 1996.

Yamane, N.; Arikawa, J.; Odagiri, T. \& Ishida N. Characterization of avian paramyxoviruses isolated from feral ducks in northern Japan: the presence of three distinct viruses in nature. Microbiol. Immunol., 26:557-68, 1982.

Zhang, G.O.; Zhao, J.X.; Wang, H.W.; Yang, A.M.; Bu, C.Y. \& Wang, M. Isolation, identification, and comparison of four isolates of avian paramyxovirus serotype 2 in China. Avian Dis., 50(3):38690, 2006.

Correspondence to:

Prof. Dr. Marcia Catroxo

Electron Microscopy Laboratory

Research and Development Center in Animal Health

Biological Institute of São Paulo

Av. Conselheiro Rodrigues Alves, 1252

CEP 04014-002

Vila Mariana

São Paulo, SP

BRAZIL

e-mail: catroxo@biologico.sp.gov.br

Received: 26-11-2011

Accepted: 19-02-2012 